Original scientific article

\title{
THE NATECH RISK ASSOCIATED TO MINING ACTIVITY IN MARAMUREŞ COUNTY, ROMANIA
}

\author{
Eugen Nour*, Irina Smical **1, Adriana Muntean*** \\ * Environmental Sciences Department, Babeş-Bolyai University of Cluj-Napoca \\ ** Faculty of Mineral Resources and Environment, Technical University of Cluj-Napoca \\ North University Centre of Baia Mare \\ ***Maramureș Water Management System, Someș-Tisa Basinal Water Administration, \\ Baia Mare City
}

Извод: Регија Марамуреш је позната по изразитом утицају експлоатације обојених руда на квалитет животне средине. За процену Natech ризика јаловишта у односу на климатске услове, посебно на количину и расподелу падавина, разматрана су четири јаловишта са потенцијалом за ширење загађења изван граница државе: Аурул, Новац, Цолбу 1 и Цолбу 2 јаловишта. У методологији, за прелиминарну анализу ризика од хазарда, обе несреће током периода од 2000. до 2010. године, и услови који се односе на изградњу и локацију јаловишта, узети су у обзир. Новац, Цолбу 1 и Цолбу 2 јаловишта су презервирана и налазе се под перманентним мониторингом, тако да је ризик од ширења загађујућих материја преко границе процењен као врло низак. У овим условима, Natech ризик је процењен само за јаловиште Аурел, тренутно једино активно јаловиште у Марамурешу. Резултати ове процене указују на средњевисок ниво ризика повезаним са екстремним метео-климатским феноменом осетљивим на регионалне климатске промене.

Кључне речи: ризик, хазард, Natech, јаловиште, рударство

\begin{abstract}
The Maramureș County is well-known as a strongly influenced area by mining exploitation of non-ferrous ores. To assess the Natech risk associated to tailing ponds in relation to climatic conditions and in particular to the rainfall in the area, four ponds with transboundary pollution potential were considered, namely: Aurul tailing pond, Novăț tailing pond, Colbu 1 tailing pond and Colbu 2 tailing pond. In the methodology for the preliminary hazards analysis both historical accidents during 2000-2010 period and the conditions related to the construction and location of the tailing ponds were taken into account. Since the Novăț taling pond, Colbu 1 tailing pond and Colbu 2 tailing pond are now preserved and permanently post-closure monitored, the transboundary risk has been estimated as being low. In these circumstances the Natech risk has been assessed only for the Aurul tailing pond which, at the present, is the only one active tailing pond in Maramureș Coun-
\end{abstract}

${ }^{1}$ Correspondence to: irina.smical@yahoo.com 
ty. The assessment results revealed a medium-high risk associated to the extreme meteo-climatic phenomena influenced by the regional climate changes.

Keywords: risk, hazard, Natech, tailing pond, mining

Date submitted: 5 January 2015; Date accepted: 25 March 2015

\section{Introduction}

Technological risk is associated with any event as a result of human activity, voluntary or involuntary, which gives the likelihood to function between normal and dangerous limits up to disasters that affect the public safety, properties or heritage values (Bălteanu \& Alexe, 2001).

A Natech disaster is a technology disaster triggered by any type of natural disaster, resulting in negative effects on people, property and the environment (Șerban \& Bălteanu, 2005).

Located in NW Romania, Maramureș County is known for centuries, mainly through its mining activities related to polymetallic non-ferrous ores, and especially silver and gold ones (Fodor, 2005; Bălănescu et al., 2002).Definitive shutting down of these operations, in the late of 2006, in conjunction with discontinued funding and insufficient maintenance of the 17 tailing ponds, have posed a major issue for the specialists in evaluating the potential technological risks (Vasilescu et al., 2012).

Given the orographic conditions of the Maramureș County, the transport infrastructure, objectives, heritage, economic institutions that use or produce hazardous substances (as raw or secondary materials), it can be said that the county is predisposed to various risks from the natural risks to the technological ones.

In Maramureș County, several technological accidents at tailings have taken place from which the most publicized were the Aurul accident in $30^{\text {th }}$ January 2000 and the Novăț accident in 10 ${ }^{\text {th }}$ March 2000 (Driga \& Basarab, 2010; Bird et al., 2008; Cordoș et al., 2006; Macklin et al., 2003).Therefore, the identification of the Natech hazards is the appropriate tool in determining the best actions to prevent and/or minimize the losses associated with these risks (Ozunu et al., 2011; Hartmann et al., 2004).

The main aim of this study is to define the Natech risks with potential transboundary effects correlated to meteo-climatic hazards in relation with the secure of some tailing ponds in Maramureș County. 


\section{Materials and methods}

\section{Considerations on the studied areas}

In Maramureș County, in the last two decades, technological accidents related to mining activity have been recorded as having major consequences which imposed prevention measures. Some of them are associated with the meteo-climatic events (Hartmann et al., 2013). Two of these accidents with transboundary consequences were the Aurul accident and the Novăt accident, that took place both in 2000 (Bird et al., 2008; Driga \& Zaharia, 2010; Macklin et al., 2003; Mara et al., 2011).

A similar accident but with much lower impact and no transboundary impact took place in $25^{\text {th }}$ november 2005 at BaiaBorșa Mining Exploitation resulting in a pollution of the Vişeu river with cyanide and heavy metals (Mara et al., 2011).The Novăt tailing pond is a valley pond on which the waste deposition was banned since December 2006 (Fig.1).

The two Colbu 1 and Colbu 2 ponds (Fig. 1) which are also valley ponds belong to Colbu mining area that is located in the east of Borșa (about 2 $\mathrm{km}$ away). These tailing ponds were put into service in 1986 (Colbu 1) and in 1989 (Colbu 2), respectively (Driga \& Basarab, 2010).

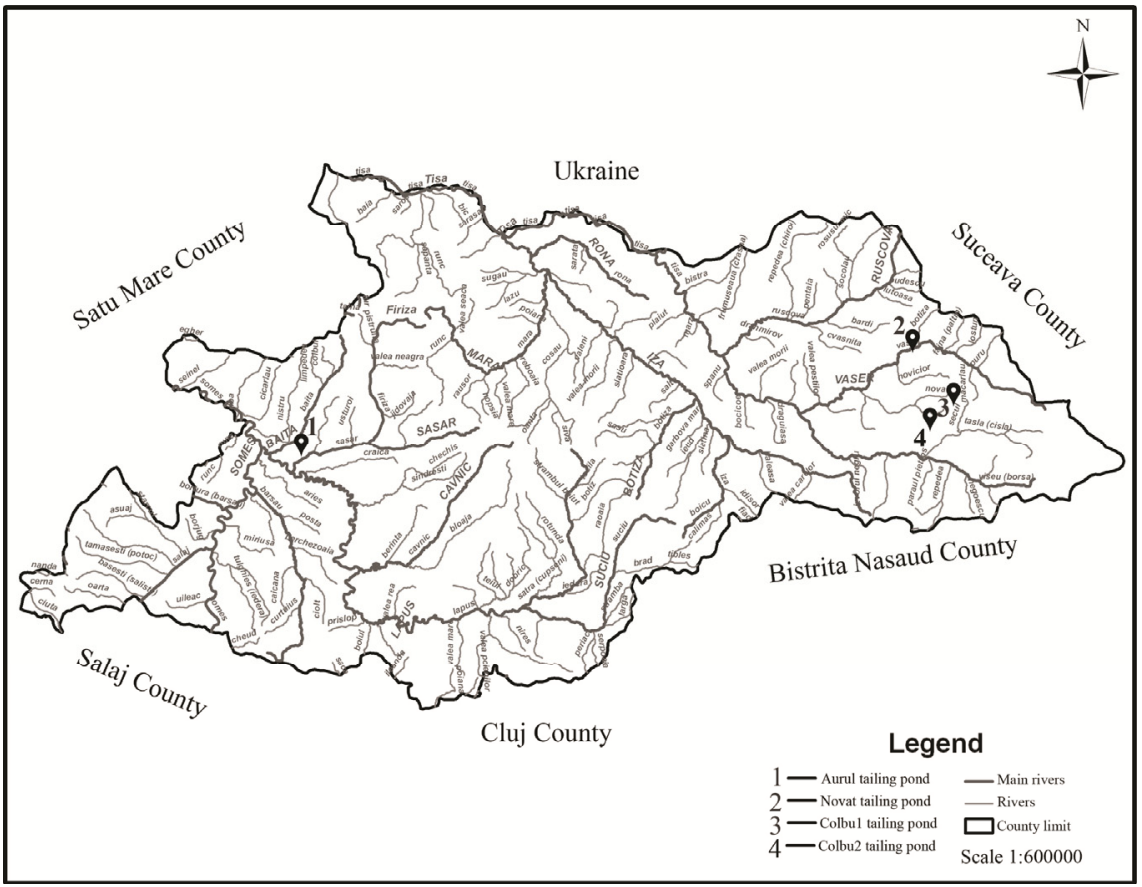

Figure 1 - Location of the Aurul, Novăț, Colbu 1 and Colbu 2 tailing ponds in Maramureș County 
The history of these ponds recorded each one a Natech type accident that took place due to the hydro-meteorological instability. Such was the case of Colbu pond on the $6^{\text {th }}$ May 1997 when after the snowmelt, and hence increasing the water flow in the Colbu Valley, the link dam of Colbu 1 and Colbu 2 ponds was broken. Through the created gap approx. $52,000 \mathrm{~m}^{3}$ of solid and liquid material flowed (Driga \& Basarab, 2010).

Tisa basin covers an area of $4,540 \mathrm{~km}^{2}$. To the north it is bordered by the Păduroși Carpathians (Ukraine), to the south by Maramureș Depression, to the west by Oaş-Gutâi Mountains and to the east by the Maramureșului Mountains (Posea et al., 1980). Tisa river flows from the Păduroși Carpathians mountains (Ukraine) and discharges into the Danube on Serbian territory. From Maramureș County it captures a number of rivers including the Vişeu river and its tributaries. The Vișeu river connects the Tisa river to the Borsa tailings ponds Colbu 1 and Colbu 2 (ME, 1992).

Aurul tailing pond (fig. 1) is a lowland pond, located in the Someș-Crasna hydrographic Basin, east of the Baia Mare City and in the vicinity of Bozânta Mare and Săsar villages. The hydrographic network is represented in south western by the Săsar river and southern by the Lăpuș River. Once they are confluent in south west of Aurul tailing pond their water flows into the Someș river (Posea et al., 1980; Ujvári, 1972). Someș river flows from Rodnei Mountains (Eastern Carpathians) and has a riverbed length of $376 \mathrm{~km}$ on Romanian territory. Baia Mare depression is crossed by the middle course of Someș river which collects the Lăpuș river and Săsar river waters then crosses the Satu-Mare County area and flows into the Tisa River in Hungary (ME, 1992; Ujvári, 1972).

Taking into account that the depositing activity was banned for the Novăt tailing pond in 2006, for the Colbu 1 tailing pond in 2002 and for the Colbu 2 tailing pond in 1997, and afterwards the tailings have been preserved and post-closure monitored, it was considered that the Natech risk associated to them and meteo-climatic conditions has been minor. Therefore, the only pond for which the Natech risk in relation with the meteo-climatic conditions was assessed was the Aurul tailing pond which is an active pond with the depositing activity temporary suspended (EPA MM, 2014; NCPBM Remin SA, 2014).

\section{The methodology of the Natech risk assessment for the Aurul tailing pond correlated with the meteo-climatic hazard}

The methodology of the systematic risk analysis is based on the definitions of Directive 96/82/EC on the control of major-accident hazards involving dangerous substances, amended by Directive 2003/105/EC of the European Parliament and of the Council of 16 December 2003. The general steps of the systematic risk analysis are: preliminary analysis, criterial analysis, detailed analysis, results and conclusions. 
The Natech hazard with crossborder potential effect associated to mining activity...

The Natech risk assessment for the Aurul tailing pond has been based on two approaching directions: one regarding the ponds location and the history of the accidents correlated with the meteo-climatic conditions in the county and the latter direction based on a preliminary hazards analysis, and the risk assessment on the likelihood and consequences gravity in an accident case. For the first stage of assessment the data provided by the Environmental Protection Agency of Maramures County and NCPBM Remin SA were used and for the latter stage of the assessment, information provided by the tailing pond operator was used. The preliminary hazard analysis was carried out based on the matrix model used by Ozunu (2000), Ozunu and Anghel (2007), Török et al. (2011).

Table 1 - The matrix of risk levels

\begin{tabular}{|c|c|c|c|c|c|c|c|}
\hline & \multicolumn{5}{|c|}{ Consequences } \\
\hline & & & Insignificant & Minor & Moderate & Major & Catastrophic \\
\hline & & & 1 & 2 & 3 & 4 & 5 \\
\hline \multirow{5}{*}{ 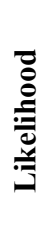 } & Unlikely & 1 & 1 & 2 & 3 & 4 & 5 \\
\hline & Less likely & 2 & 2 & 4 & 6 & 8 & 10 \\
\hline & Possible & 3 & 3 & 6 & 9 & 12 & 15 \\
\hline & Likely & 4 & 4 & 8 & 12 & 16 & 20 \\
\hline & $\begin{array}{l}\text { Almost } \\
\text { certainly }\end{array}$ & 5 & 5 & 10 & 15 & 20 & 25 \\
\hline
\end{tabular}

Source: Ozunu \& Anghel, 2007.

It allows the assessment of the risk occurrence and its level of severity (Török et al, 2011). Based on the identification of the causes that could trigger the event, assessing the short and long term consequences and their severity, effective preventive measures ought to be implemented to minimize the disastrous effects of the hazard, thus preventing the transformation of the hazard event into an accident (Török et al., 2001).

Also a quantitative risks assessment was carried out by approaching the likelihood and the consequences severity on a 1 to 5 scale. The risk value was calculated as a result of the two factors: likelihood and consequences severity according to the below relation used by Ozunu (2000), Ozunu and Anghel (2007), Török et al. (2011).

$$
\mathrm{R}=\mathrm{L} \times \mathrm{C},
$$

where - $\mathrm{L}$ is the likelihood of an event; $\mathrm{C}$ is the consequences severity.

The measure of the likelihood is qualitatively established by a series of five severity levels from "unlikely" to the "almost certainly". The quantitative measure of the consequences is also established by means of five severity levels from "insignificant" to the "catastrophic", resulting in a risk matrix. Risk 
assessment matrices have been used for many years in the risk classification (Table 1, 2) (Ozunu, 2000; Ozunu \& Anghel, 2007).

Table 2 - Risk levels and measures

\begin{tabular}{|c|c|c|}
\hline $\begin{array}{l}\text { Risk } \\
\text { levels }\end{array}$ & Definition & Actions to be taken \\
\hline $1-3$ & Very low risk & \multirow{2}{*}{$\begin{array}{l}\text { The management of actions by common and routine } \\
\text { procedures }\end{array}$} \\
\hline $4-6$ & Low risk & \\
\hline $7-12$ & Moderate risk & $\begin{array}{c}\text { The specific standard operating procedures involving } \\
\text { workplace leadership }\end{array}$ \\
\hline $13-19$ & High risk & $\begin{array}{l}\text { Prompt action taken as soon as the management normal sys- } \\
\text { tem allows with the involvement of the senior management }\end{array}$ \\
\hline $20-25$ & Extreme risk & Immediate action with priority use of all available resources \\
\hline
\end{tabular}

Source: Ozunu \& Anghel, 2007.

The specialists in meteorology especially warn about the rainfalls features in relation with the climate changes. In the last decades some uncommon hydro-meteorological events taken place all over the world. Now, the most dangerous particularity of the rainfalls consists in their intensity but their large amounts are also important (Fig. 2) (NMA, 2014).

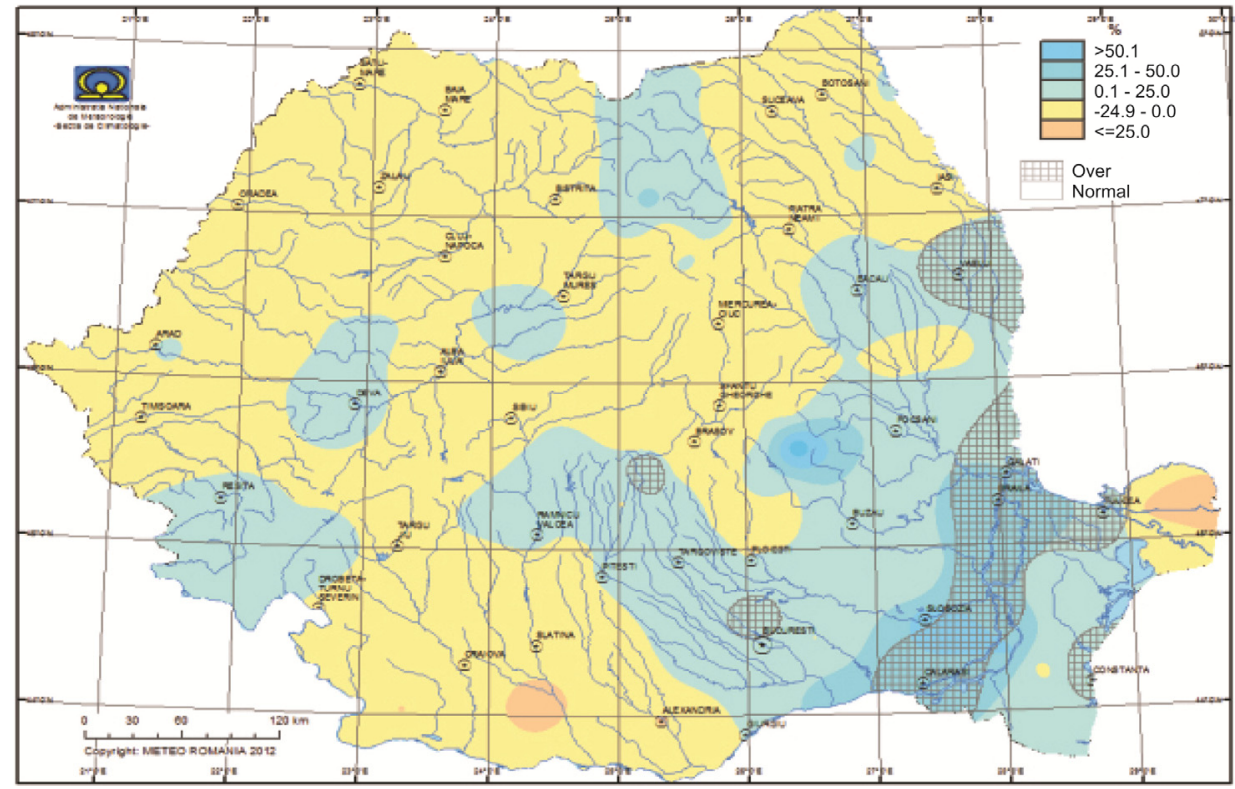

Figure 2 - Deviation of annual precipitation in 2012, compared to the standard climatological normal (1961-1990) (NMA, 2014) 
According to the Security Report of Aurul tailing pond to ensure the pond secure and its stability the following criteria must be respected (SCOE, 2012):

- maximum gradient of the outer slope of 1:3;

- the minimum width of the beach of $20 \mathrm{~m}$;

- minimum guard of the outside dam of $1.20 \mathrm{~m}$;

- particles size of the deposited material and a low level of the depression curve in the pond body.

It is important to note that all the above factors play an important role in the stability of the dam, especially in periods of heavy rainfall.

Studies of qualitative assessment of the risk for the Aurul tailing pond pointed out that "the highest risk is associated to the dam breaking (formation of a rift), leading to uncontrolled loss of cyanide contaminated water and some contaminated tailings into environment" (table 3) (SCOE, 2012).

Table 3 - Quantifying the risks associated to climatic hazards

\begin{tabular}{|c|c|c|c|}
\hline Type of hazard & $\mathrm{P}^{*}$ & $\mathrm{G}^{*}$ & $\mathrm{R}^{*}$ \\
\hline The break of the total contour dam & 1 & 4 & $\mathbf{4}$ \\
\hline Formation of rifts in the contour dam & 2 & 3 & $\mathbf{6}$ \\
\hline The rift of the geomembrane & 2 & 3 & $\mathbf{6}$ \\
\hline The breaking or cracking the slurry distribution pipes & 4 & 1 & $\mathbf{4}$ \\
\hline Serious damage of the drainage system & 3 & 2 & $\mathbf{6}$ \\
\hline P*- danger $\mathrm{G}^{*}$ - gravity, $\mathrm{R}^{*}$ - risk
\end{tabular}

Source: SC OCON Ecorisc Ltd., 2012.

Therefore, the risk quantification related to the formation of a rift in the contour dam of the pond was periodically empirically assessed considering the tailing pond as a system of whose natural components have direct implications in triggering the event. Every involved event has been characterized by a gravity index (IG) on a scale from 1 to 5, and calculated by the equation (SCOE, 2012):

$$
\mathrm{IG}=\mathrm{CM} \times \mathrm{PC} \times \mathrm{DC},
$$

where $\mathrm{CM}$ is a partial index expressing the share of the component failure in breaking triggering; $\mathrm{PC}$ is a partial index which expresses the likelihood of the component failure; DC is a partial index that expresses the extent to which the component failure could be detected in advance.

So it is estimated that the maximum value of the gravity index of 125 may be reached by triggering a very long before detected event $(\mathrm{DC}=5)$, by triggering a release mechanism $(\mathrm{CM}=5)$ and very probable deviation of the safety conditions $(\mathrm{PC}=5)$. 
Consultations on dam safety have allowed identification of the elements with potential rift triggering in the pond body. These elements are presented in table 4.

Table 4 -Elements potentially initiating the formation of rift in the body pond

\begin{tabular}{|c|c|c|c|c|c|}
\hline \multicolumn{2}{|c|}{ Parameter or component } & $C M$ & $P C$ & $D C$ & $\begin{array}{c}I G= \\
=C M x P C x D C\end{array}$ \\
\hline I & The gutter guard pond & 5 & 4 & 1 & 20 \\
\hline II & Beach width & 4 & 4 & 1 & 16 \\
\hline III & Downstream embankment slope & 5 & 4 & 1 & 20 \\
\hline IV & $\begin{array}{c}\text { Material granulometry of the downstream } \\
\text { slope }\end{array}$ & 3 & 4 & 3 & 36 \\
\hline V & The system of clarified water collection & 5 & 3 & 4 & 60 \\
\hline VI & The drainage system & 5 & 2 & 4 & 40 \\
\hline VII & $\begin{array}{c}\text { The pumping station of the clarified and } \\
\text { drained waters }\end{array}$ & 2 & 3 & 1 & 6 \\
\hline VIII & The outlet & 3 & 4 & 2 & 24 \\
\hline
\end{tabular}

Source: SC OCON Ecorisc Ltd., 2012.

Based on previous qualitative assessment, the prioritizing risks of a rift formation is: $\mathrm{V}>\mathrm{VI}>\mathrm{IV}>\mathrm{VIII}>\mathrm{III}=\mathrm{I}>\mathrm{II}>\mathrm{VII}$.

For assessing the likelihood of forming a rift the tree of the adverse events has been used (Ozunu \& Anghel, 2007). The risk quantification by the annual likelihood defining of the primary events such as rainfall, follows a simple statistically procedure of identifying the annual peaks based on numerical assessment (Table 5) (McLeods \& Plewes, 1999).

To simplify the means of identification and assessment of natural events, the likelihood of high-intensify rainfall was considered, which corresponds to the importance class of $0.1 \%$. It was also taken into account the probability of exceptional rainfall situation which correspond to the situation of sizing the excessive water flow that have to be discharged from the pond (overlapping excessively wet year (1\%) with exceptional rainfall (0.1\%) (SCOE, 2012).

Table 5 - Associated risks with equivalent examples

\begin{tabular}{|c|c|c|c|}
\hline Degree & $\begin{array}{c}\text { Annual } \\
\text { Likelihood }\end{array}$ & Description & Equivalent examples \\
\hline Insignificant & $<10^{-6}$ & $\begin{array}{c}\text { Almost } \\
\text { impossible }\end{array}$ & $\begin{array}{c}\text { Death caused by the fall of a mete- } \\
\text { orite }\end{array}$ \\
\hline Very low & $10^{-4} \ldots 10^{-6}$ & $\begin{array}{c}\text { Very least } \\
\text { possible }\end{array}$ & $\begin{array}{c}\text { Incidence of death caused by direct } \\
\text { lightning }\end{array}$ \\
\hline Low & $10^{-2} \ldots 10^{-4}$ & It is possible & Death due to cancer illness \\
\hline Moderate & $10^{-1} \ldots 10^{-2}$ & It will happen & Death due to traffic accident \\
\hline High & $>10^{-1}$ & It often happens & Current accident due to traffic \\
\hline
\end{tabular}

Source: after McLeods \& Plewes, 1999. 
Excepting that there may be deviations from the operating conditions of the tailing pond it was found that the uncontrolled loss of water from the pond could take place due to the spill over dam shape, either through a gap created by the slipping the downstream slope, both as a result of high rainfall intensity, exceptional rainfall, with or without fast snow melting.

\section{Conclusions}

Of the 17 tailing ponds located in Maramureș County only 4 of them might pose a transbourdary risk in Natech context, like: Aurul tailing pond, Novăț tailing pond, Colbu 1 tailing pond and Colbu 2 tailing pond. From these only Aurul tailing pond is still active but have the activity suspended since 2006. The other three tailing ponds mentioned above, are shut down and preserved being post-closed monitored. In this context, only the Natech risk associated to the Aurul tailing pond has been assessed correlated with the meteoclimatic conditions and especially to the extreme events.

The risk study for Aurul tailing pond revealed that the exceptional rainfalls have the most important share $(58.1 \%)$ in production of the dam rift by sliding of the downstream slope. Based on this the Natech risk should be included in the medium-high risk associated to the extreme meteo-climatic phenomena influenced by the regional climate changes.

Without taking into account the directly produced damages for the company, the alert rhythm of losing the content of the tailing pond, may produce serious consequences that are difficult to measure: loss of life; material loss, damage effects on the entire ecosystem.

The disaster prevention by identifying the Natech risks allows operative remedial interventions. The study highlights the fact that the violent and abundant rainfall, the steep differentiation of day-night temperatures are the most important meteo-climatic factors in the rifts occurrence in the downstream slope of the Aurul pond.

The study highlights the possibility of a Natech risk associated to the Aurul tailing pond and reveals the importance of monitoring the meteo-climatic phenomena by the pond operator in conjunction with the institutes and authorities which provide and carry out activities related to the meteo-climatic phenomena to take the best decisions in preventing the major accidents.

\section{References}

Bălănescu, S., Achim, V., \& Ciolte, A. (Eds). (2002). The History of Management Mining of Non-ferrous and Precious Metalurgy in Northern-Western of Romania. Baia Mare: Gutinul Press. 
Bălteanu D., \& Alexe R. (Eds). (2001). Hazarde naturale şi antropice. Bucureşti: Corint Press.

Bird, G., Brewer, P.A., Macklin, M.G., Bălteanu, D., Șerban, M., Driga, B., \& Zaharia, S. (2008). River system recovery following the Novaț-Roșu tailings dam failure, Maramureș County, Romania. Applied Geochemistry, 23, 3498-3518.

Cordoș, E., Răuţiu, R., Roman, C., Ponta, M., Frențiu, T., Sarkany, A., Fodorpataki, L., Macalik, K., McCormick, C., \& Weiss, D. (2006). Characterisation of the rivers system in the mining and industrial area of Baia Mare, Romania. European Journal of Mineral Processing and Environmental Protection, 3, 324-335.

Driga, B., \& Zaharia, S. (Eds). (2010). Hazardele Naturale și Miniere din Bazinul Vişeu. Proceedings from Conference ,Water resources from Romania. Vulnerability to the pressure of man's activities". Târgovişte, România.

Environmental Protection Agency of Maramureș County (EPA MM) (2014). Report of environment for 2013. Retrieved from: http://www.anpm.ro/documents/23445/2513172/07_CAP_IV_2013Utilizarea terenurilor.pdf/0c36d506-71b4-4376-9551-f55e-88592e5c

Fodor, D. (Eds). (2005). Pages from Mining History. Deva: Infomin Press.

Hartmann, D.L., A.M.G. Klein Tank, Rusticucci, M., Alexander, L.V., Brönnimann, S., Charabi, Y., Dentener, F.J., Dlugokencky, E.J., Easterling, D.R., Kaplan, A., Soden, B.J., Thorne, P.W., Wild, M., \& Zhai, P.M. (2013). Observations: Atmosphere and Surface. In: Climate Change 2013: The Physical Science Basis. Contribution of Working Group I to the Fifth Assessment Report of the Intergovernmental Panel on Climate Change [Stocker, T.F., D. Qin, G.-K. Plattner, M. Tignor, S.K. Allen, J. Boschung, A. Nauels, Y. Xia, V. Bex and P.M. Midgley (eds.)]. Cambridge University Press, Cambridge, United Kingdom and New York, NY, USA.

Hartmann, J., Okada, N. \& Levy, L.K. (2004). Integrated disaster risk management strategy to prevent exposure to hazardous substances due to inundation triggered releases: a concept for Japan. Journal of Natural Disaster Science, 26 (2), 87-93.

Macklin, M.G., Brewer, P.A., Bălteanu, D., Coulthard, T.J., Driga, B., Howard A.J., \& Zaharia, S. (2003). The long term fate and environmental significance of contaminant metals released by the January and March 2000 mining tailings dam failures in Maramureș, County, upper Tisa Basin, Romania. Applied Geochemistry, 18, 241-257.

Mara, S., Adler, M.J., \& Hamchevici, C. (Eds). (2011). Qualitative and quantitative analysis methods in the assessment of industrial accidents occurrence, with accidental pollution of surface waters: case study for the ponds of waste decantation from the mining and chemical processing industry. Paper presented at Annual Conference of the National Institute of Hydrology and Water Management from Romania. Bucureşti, România. 
The Natech hazard with crossborder potential effect associated to mining activity...

McLeod, H., \& Plewes, H. (Eds.). (1999). Risk Management Analysis (RMA). Proceedings Canadian Dam Safety Conference.

Ministry of Environment (ME) (1992). Cadastre Atlas of Water from Romania - Part 1. Morpho-hydrographic Data on the Hydrographical Network. Bucureşti: Aquaproiect S.A. Press.

National Company of the Precious and Base Metals "REMIN" S.A., (NCPBM Remin SA) (2014). Technical data and information.

National Meteorological Administration (NMA) (2014). Annual Report for 2012. Retrieved from: http://www.meteoromania.ro/anm/?page_id=2628.

OCON Ecorisc Ltd. (SCOE) (2012). Raport de securitate SC Romaltyn Mining Ltd. Retrieved from: http:/www.romaltyn.ro/autorizare-mediu/

Ozunu, A. \& Anghel, C.I. (Eds). (2007). Evaluarea riscului tehnologic și securitatea mediului. Cluj-Napoca: Accent Press.

Ozunu, A., Senzaconi, F., Botezan, C., Ștefănescu, Nour, E., \& Balcu, C. (2011). Investigations on natural hazards which trigger technological disasters in Romania. Natural Hazards and Earth System Sciences, 11, 1319-1325.

Ozunu, A. (Eds). (2000). Elemente de hazard şi risc în industriile poluante. Cluj-Napoca: Accent Press.

Posea, G., Moldovan, C., \& Posea, A. (Eds). (1980). Homeland counties. Maramureș County, Bucharest: Socialist Republic of Romania Press.

Şerban, M., \& Bălteanu, D. (2005). Hazardele tehnologice induse de hazardele naturale (NATECH) în contextul modificărilor globale ale mediului. Environment \& Progress, 4, 591-595.

The European Parliament and of the Council of the European Union (1996). Directive 96/82/EC of the European Parliament and of the Council of 9 December 1996 on the control of major-accident hazards involving dangerous substances. Official Journal of the European Union. Retrieved from: http://eur-lex.europa.eu/

The European Parliament and of the Council of the European Union (1996). Directive 2003/105/EC of the European Parliament and of the Council of 16 December 2003 amending Council Directive 96/82/EC on the control of major-accident hazards involving dangerous substances. Official Journal of the European Union. Retrieved from: http://eurlex.europa.eu/LexUriServ/LexUriServ.do?uri=OJ:L:2003:345:0097:0105 :EN:PDF

Török, Z, Ajtai, N., \& Ozunu, A. (2011). Computing applications for risk assessment of major industrial accidents involving dangerous substances. The Publishing Foundation for European Studies, 117.

Ujvári, I. (Eds). (1972). Water Geography of România. Bucureşti: Scientific Press. Vasilescu, I., Smical, I., \& Pop, I. (2012). The Impact of Mining Industry on the Landscape of Maramureș County. Present Environment and Sustainable Development, VI (2), 253-260. 
Оригинални научни рад

Eugen Nour, Irina Smical, Adriana Muntean

\section{NАТЕСН ХАЗАРД У ВЕЗИ СА РУДАРСТВОМ У МАРАМУРЕШУ У РУМУНИЈИ}

\section{Резиме}

Од 17 јаловишта у Марамурешу, само четири имају потенцијал да постану преко гранични загађивачи у Natech контексту, то су: Аурул, Новац, Цолбу 1 и Цолбу 2 јаловишта. Од поменутих само Аурул јаловиште је активно, при чему је његова активност суспендована од 2006. године. Три преостала јаловишта су затворена, презервирана и налазе се под мониторнигом. У овом раду, имајући у виду метеоклиматским условима, посебно екстремне метеоролошке појаве, извршена је процена Natech ризика за Аурул јаловиште. Студија процене ризика за Аурул јаловиште указује на то да непредвиђено велике количине падавина имају најзначајнију улогу $(58,1 \%)$ у покретању клизишта и пукотина на брани јаловишта. На основу Natech ризика треба да буду укључени у средње-високом ризику повезаним са екстремним метео-климатским феноменом осетљивим на регионалне климатске промене. Не узимајући у обзир директну штету за компанију, убрзан ритам губитка садржаја јаловишта може произвести озбиљне последице: губитак живота, материјални губитак, негативне ефекте на целокупан екосистем и сл. Превенција катастрофа идентификовањем Natech ризика дозвољава корективне оперативне интервенције. Студија указује на чињеницу да су снажне и обилне падавине и велике разлике у варијацијама дневних и ноћних температурама ваздуха, најважнији метео-климатских фактор настанка клизишта на падини јаловишта Аурул. Студија наглашава значај процене Natech ризика за Аурул јаловиште и открива значај праћења метео-климатског феномена од стране оператера јаловишта повезаним са институтима и надлежнима који имају функцију обезбеђивања и спровођења активности у вези са метео-климатским феноменом и предузимања најбољих одлука при превенцији од већих акцидената. 